Key Biodiversity Area Special Series

\title{
Key Biodiversity Areas identification in Japan Hotspot
}

\author{
Yoji Natori ${ }^{1}$, Mari Kohri ${ }^{2}$, Seiji Hayama ${ }^{3}$ \& Naamal De Silva ${ }^{4}$ \\ 1,2 Conservation International Japan, Shinjuku i-Land Tower 39F, 6-5-1 Nishi-Shinjuku, Shinjuku-ku, Tokyo 163-1339, Japan \\ ${ }^{3}$ Wild Bird Society of Japan, 3-9-23 Nishi-gotanda, Shinagawa-ku, Tokyo 141-0031, Japan \\ ${ }^{4}$ Conservation International, 2011 Crystal Drive, Suite 500, Arlington, VA 22202, USA \\ Email: ${ }^{1}$ y.natori@conservation.org (corresponding author), ${ }^{2}$ kohrim@tmu.ac.jp, ${ }^{3}$ hayama@wbsj.org, \\ ${ }^{4}$ n.desilva@conservation.org
}

Date of publication (online): 06 August 2012 Date of publication (print): 06 August 2012 ISSN 0974-7907 (online) | 0974-7893 (print)

\section{Manuscript details:}

Ms \# o2999

Received 08 November 2011

Final revised received 26 December 2011

Finally accepted 04 June 2012

Citation: Natori Y., M. Kohri, S. Hayama \& N. De Silva (2012). Key Biodiversity Areas identification in Japan Hotspot. Journal of Threatened Taxa 4(8): 2797-2805.

Copyright: (c) Yoji Natori, Mari Kohri, Seiji Hayama \& Naamal De Silva 2012. Creative Commons Attribution 3.0 Unported License. JoTT allows unrestricted use of this article in any medium for non-profit purposes, reproduction and distribution by providing adequate credit to the authors and the source of publication.

Author Details, Author Contributions \& Acknowledgements: See end of this article.

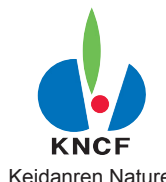

Keidanren Nature

Conservation Fund

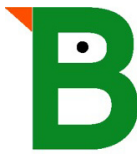

\section{公益財団法人}

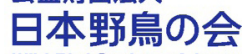

wild Bird Society of Japan

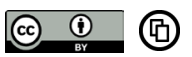

OPEN ACCESS | FREE DOWNLOAD

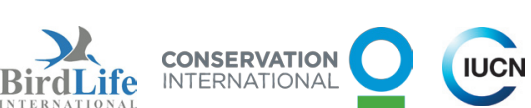

\begin{abstract}
Priority sites within Japan Hotspot were identified using Key Biodiversity Area (KBA) criteria, based on vulnerability and irreplaceability. The identification process considered 217 trigger species from mammals, birds, reptiles, amphibians, freshwater and brackish water fishes and odonates, and focused on identifying gaps in Japan's protected-area system. We identified 228 sites as KBAs and 50 rivers as candidate KBAs. Collectively, KBAs occupy $18 \%$ of the land, about half is not protected. Sites selected include natural and semi-natural environments, and appropriate form of protection is site-dependent. Twenty percent of Japanese terrestrial area is already protected, although to varying degrees, but additional $8 \%$ should also receive protection or proper management to strengthen the conservation of biodiversity in Japan.
\end{abstract}

Keywords: conservation priority, Aichi Target, red list, GIS, IBA, Key Biodiversity Area, KBA, vulnerability, irreplaceability

Japanese Abstract: 危機性および非代替性といらKBA 基準に則り、生物多様性ホットスポ ッ下である日本列島の保全上の優先地域を抽出した。哺乳類、鳥類、爬虫類、両生類、淡水・ 汽水魚類、トンボ類の計 217 種を対象とし、日本で現在指定されている保護地域には含まれ ていない重要地域(ギャップ)を明らかにすることに重点をおいた。KBA として選ばれた 228 ケ 所の総面積は国土の18\%を占めるが、このほぼ半分が保護されていないことが分かった。さ らに、50の河川をKBA 候補としている。KBA には自然度の高い地域から人手が加わった自 然までが含まれているため、適切な保護の形態はそれぞれの地域の状況に合わせて検討さ れる必要がある。現在、国土の $20 \%$ が何らかの保護地域に指定されているが、本調査結果か ら、日本の生物多様性保全のためには、さらに $8 \%$ につて適切な管理が担保される必要が あると言える。

\section{INTRODUCTION}

The Japanese archipelago stretches $3,000 \mathrm{~km}$ from the sub-tropics in the south to the sub-Arctic in the north. Although the four main islandsHokkaido, Honshu, Shikoku and Kyushu_-account for much of Japan's land area (approximately 375,000 $\mathrm{km}^{2}$ ), collections of smaller islands support relatively high levels of biodiversity. As a heavily populated, industrialized nation, there are few unmodified areas, but high biodiversity is still seen. Owing to this, the archipelago has been identified as one

The Key Biodiversity Area series documents the application of the concept and showcases the results from various parts of the world. The series is edited under the auspices of the IUCN World Commission on Protected Areas/Species Survival Commission Joint Task Force on 'Biodiversity and Protected Areas', with the editors supported by BirdLife International, Conservation International, IUCN, National Fish \& Wildlife Foundation, NatureServe, Parks Canada, and Plantlife International. 
of the world's 35 Biodiversity Hotspots (Mittermeier et al. 2004; Williams et al. 2011) with nearly 2,000 endemic vascular plants (Kato \& Ebihara, 2011; Mittermeier et al. 2004). Besides the more natural landscapes, human-influenced habitats often made up of paddy-fields and secondary forests also play an important role in supporting the biodiversity of Japan (Natori et al. 2011; Washitani, 2001).

There is a wide range of protected area categories in the Japanese nature conservation system. The major ones include national parks, quasi-national parks, and prefectural natural areas under the Natural Parks Law; wildlife protection areas under the Wildlife Protection and Hunting Law; wilderness areas and nature conservation areas under the Nature Conservation Law; and forest reserves and forest ecosystem conservation areas under the Forestry Law. Except for the areas designated under Natural Parks Law and Nature Conservation Law, designations are mutually complementary and several designations can commonly overlap. Combining all these areas, the existing protected areas cover $20 \%$ of Japan's land surface. Additionally, the Endangered Species Law provides for the protection of designated species, and some associated habitat areas have been designated for protection. The Law for Protection of Cultural Properties, which was established much earlier than the Endangered Species Law, also protects species and sites of scientific importance (called "natural monuments"), some of which are threatened.

The selection of these existing protected areas is however not based on systematic biodiversity assessments. Therefore, important sites for biodiversity need to be identified systematically so that all such sites are known and preferably become protected. Key Biodiversity Areas (KBAs) are globally important sites for biodiversity conservation, identified based on two criteria: vulnerability and irreplaceability (Langhammer et al. 2007). It is a species-based site-selection methodology, but with the aim of site conservation. The most significant sites for bird conservation have been identified using these criteria, and there are 167 Important Bird Areas (IBAs) in Japan (Wild Bird Society of Japan, 2010). The KBA identification process adds to IBAs by bringing other taxa into consideration.

The major questions we addressed were, "Where are gaps in Japanese protected-area system that deserve protection or proper management? And what particularly significant biodiversity occurs in existing protected areas?" Our focus was less on the assessment of the performance of the existing protected areas, but more on identifying the parts of the land that still need to be protected, i.e., highlighting existing gaps.

Table 1. KBA criteria and their application in Japan

\begin{tabular}{|c|c|c|c|}
\hline Criteria & Sub-criteria & Provisional thresholds & Modification in Japan \\
\hline $\begin{array}{l}\text { Vulnerability } \\
\text { Regular occurrence of a } \\
\text { globally threatened species } \\
\text { (according to the IUCN Red } \\
\text { List) at the site }\end{array}$ & $\mathrm{N} / \mathrm{A}$ & $\begin{array}{l}\text { Critically Endangered (CR) } \\
\text { and Endangered (EN) } \\
\text { species - presence of a single } \\
\text { individual. } \\
\text { Vulnerable species (VU) - } 30 \\
\text { individuals or } 10 \text { pairs. }\end{array}$ & $\begin{array}{l}\text {-Sites with the presence record of at least one } \\
\text { CR or EN species } \\
\text { - Sites with the presence records of multiple VU } \\
\text { species } \\
\text { - Sites with species endemic to Japan listed as } \\
\text { threatened in Japan red list that are not listed } \\
\text { in the IUCN red list } \\
\text { Sites with a single VU species were } \\
\text { not identified as KBAs if that species is } \\
\text { represented in other KBAs. }\end{array}$ \\
\hline \multirow{5}{*}{$\begin{array}{l}\text { Irreplaceability } \\
\text { Site holds X\% of a species' } \\
\text { global population at any stage } \\
\text { of the species' lifecycle }\end{array}$} & a) Restricted-range species & $\begin{array}{l}\text { Species with a global range } \\
\text { less than } 50,000 \mathrm{~km}^{2} \text { and } 5 \% \\
\text { of global population at site }\end{array}$ & \multirow{5}{*}{$\begin{array}{l}\cdot \text { (Mammals and amphibians only) Species } \\
\text { with global range less than } 50,000 \mathrm{~km}^{2} \text { and } \\
\text { those with known occurrence in well-defined } \\
\text { localities } \\
\cdot \text { (Birds only) Sites meeting IBA criterion A2, A3 } \\
\text { and/or A4 }{ }^{1}\end{array}$} \\
\hline & $\begin{array}{l}\text { b) Species with large but } \\
\text { clumped distributions }\end{array}$ & $5 \%$ of global population at site & \\
\hline & $\begin{array}{l}\text { c) Globally significant } \\
\text { congregations }\end{array}$ & $\begin{array}{l}1 \% \text { of global population } \\
\text { seasonally at the site }\end{array}$ & \\
\hline & $\begin{array}{l}\text { d) Globally significant } \\
\text { source populations }\end{array}$ & $\begin{array}{l}\text { Site is responsible for } \\
\text { maintaining } 1 \% \text { of global } \\
\text { population }\end{array}$ & \\
\hline & $\begin{array}{l}\text { e) Bioregionally restricted } \\
\text { assemblages }\end{array}$ & To be defined & \\
\hline
\end{tabular}

${ }^{1}$ See Wild Bird Society of Japan (2010) for detailed definitions. 
Table 2. Numbers of species triggering each of the criteria/subcriteria for each higher taxonomic group

\begin{tabular}{|c|c|c|c|c|c|c|c|}
\hline \multirow[b]{2}{*}{ Higher taxon } & \multicolumn{3}{|c|}{ Vulnerability } & \multicolumn{3}{|c|}{ Irreplaceability } & \multirow[b]{2}{*}{ Tota } \\
\hline & CR & EN & VU & Restricted-range & $\begin{array}{c}\text { Congregations/ } \\
\text { Aggregations }\end{array}$ & Biome-restricted & \\
\hline Mammals & 5 & 13 & 1 & 9 & Not defined & Not defined & 28 \\
\hline Birds ${ }^{1}$ & 2 & 9 & 23 & 5 & $49^{2}$ & $14^{3}$ & 99 \\
\hline Reptiles & 1 & 4 & 7 & Not defined & Not defined & Not defined & 12 \\
\hline Amphibians & 2 & 14 & 3 & 10 & Not defined & Not defined & 29 \\
\hline Fish & 17 & 11 & 3 & Not defined & Not defined & Not defined & 31 \\
\hline Odonates & \multicolumn{2}{|c|}{$11^{4}$} & 7 & Not defined & Not defined & Not defined & 18 \\
\hline Total & 27 & 62 & 44 & 24 & 49 & 14 & 217 \\
\hline
\end{tabular}

${ }^{1}$ Based on the information in Wild Bird Society of Japan (2011).

${ }^{2}$ Species fulfilling the Criterion A4 of IBA as applied in Japan (Wild Bird Society of Japan, 2010). The number includes 48 species and one species group, Anatidae. Species included in the vulnerability criterion were not included here.

${ }^{3}$ Species selected for Criterion A3 (Wild Bird Society of Japan, 2010). There are three species overlapping with congregations/aggregations subcriterion, which are removed in counting the total.

${ }^{4}$ Japanese Red List for insects has one merged category for CR and EN. The total is counted under EN.

\section{METHODS}

The standard global set of criteria of vulnerability and irreplaceability (Langhammer et al. 2007) was used in selecting trigger species (Table 1). The KBA selection process took into account all terrestrial vertebrate taxa (mammals, birds, reptiles, amphibians and freshand brackish-water fish) and odonates (Table 2). For the taxa of which the IUCN Red List is incomplete or outdated, the more recent and comprehensive compilation of Japan's Red Lists were used (see below for a further discussion). When finalizing the lists of trigger species (especially when adding species that are not IUCN threatened species), we consulted with a few experts regarding the appropriateness.

The study built on the earlier work of IBA identification (Wild Bird Society of Japan, 2010), and we adopted all IBAs as KBAs. Fish and odonates were included in the analysis to give emphasis to freshwater systems, which are underrepresented in the national protected-area network.

\section{Vulnerability}

We used the IUCN threatened species list (IUCN, 2010) to define the vulnerability of trigger species of mammals and amphibians. We considered the information on threatened status of these two taxa to be up to date, because the global assessments have only recently been completed. Since IBAs were treated as KBAs automatically, bird trigger species used for IBA identification were also KBA trigger species. For other taxa, the IUCN list is incomplete and/or in need of updating. Thus, we supplemented the IUCN list with the Japan's national red lists (Ministry of the Environment, 2006, 2007). In doing so, we only considered those species endemic to Japan since these assessments represent the global status of such species (as recommended by Eken et al. (2004) p. 1114). Where the IUCN category differed from the national one, the national category was given precedence since we considered that Japan's national lists were more up to date and carried higher accountability for species endemic to Japan.

\section{Irreplaceability}

The Irreplaceability criteria were applied for mammals, birds and amphibians only. We used the range sizes of mammalian and amphibian species from the Global Assessments (IUCN, 2009), and only those with global ranges of smaller than 50,000 $\mathrm{km}^{2}$ were used (i.e., restricted-range sub-criterion). Since population information is not available for these taxa, we applied the irreplaceability criterion to only those species with known occurrence in well-defined localities, such as islands.

For birds, as was the case with vulnerability, the IBA trigger species were also KBA trigger species. IBA defined irreplaceability sub-criteria in restricted range, congregation/aggregation and biomerestriction. Unlike mammals and amphibians, the irreplaceability criterion alone was used to trigger KBAs identification for birds. For the purpose of counting trigger species in this paper, the species included in the vulnerability trigger species were not included in irreplaceability trigger species.

Although irreplaceability has not been defined for 
other taxa, many species likely to trigger sites under the irreplaceabilitycriteriaareinanycaselikely toalsotrigger identification of sites under the vulnerability criteria. This is especially the case in an insular nation like Japan.

\section{Data sources}

The species presence information was obtained from the "National Survey on the Natural Environment," conducted by the Japanese Ministry of the Environment (MOE) since 1973 (Biodiversity Center of Japan, 2008). Detailed presence information (in approximately $1 \mathrm{~km} \times 1 \mathrm{~km}$ cells, or the "third mesh" in Japanese standard gridding system) on threatened species was used with permission from the Biodiversity Center of the MOE. Published journal articles supplemented this information, particularly for bats and odonates. The "Important Wetlands 500" sites (Ministry of the Environment, 2001) that had been selected for the presence of the vulnerability trigger species were also included.

\section{KBA Identification and Delineation}

We built the identification and delineation process on the existing IBAs. To incorporate other taxa, protected areas that encompassed the locations of trigger species for non-avian taxa were first adopted as KBAs. Protected areas were not divided when delineating KBAs. We considered the following designations as protected areas for the purposes of KBA identification: national parks, quasi-national parks,

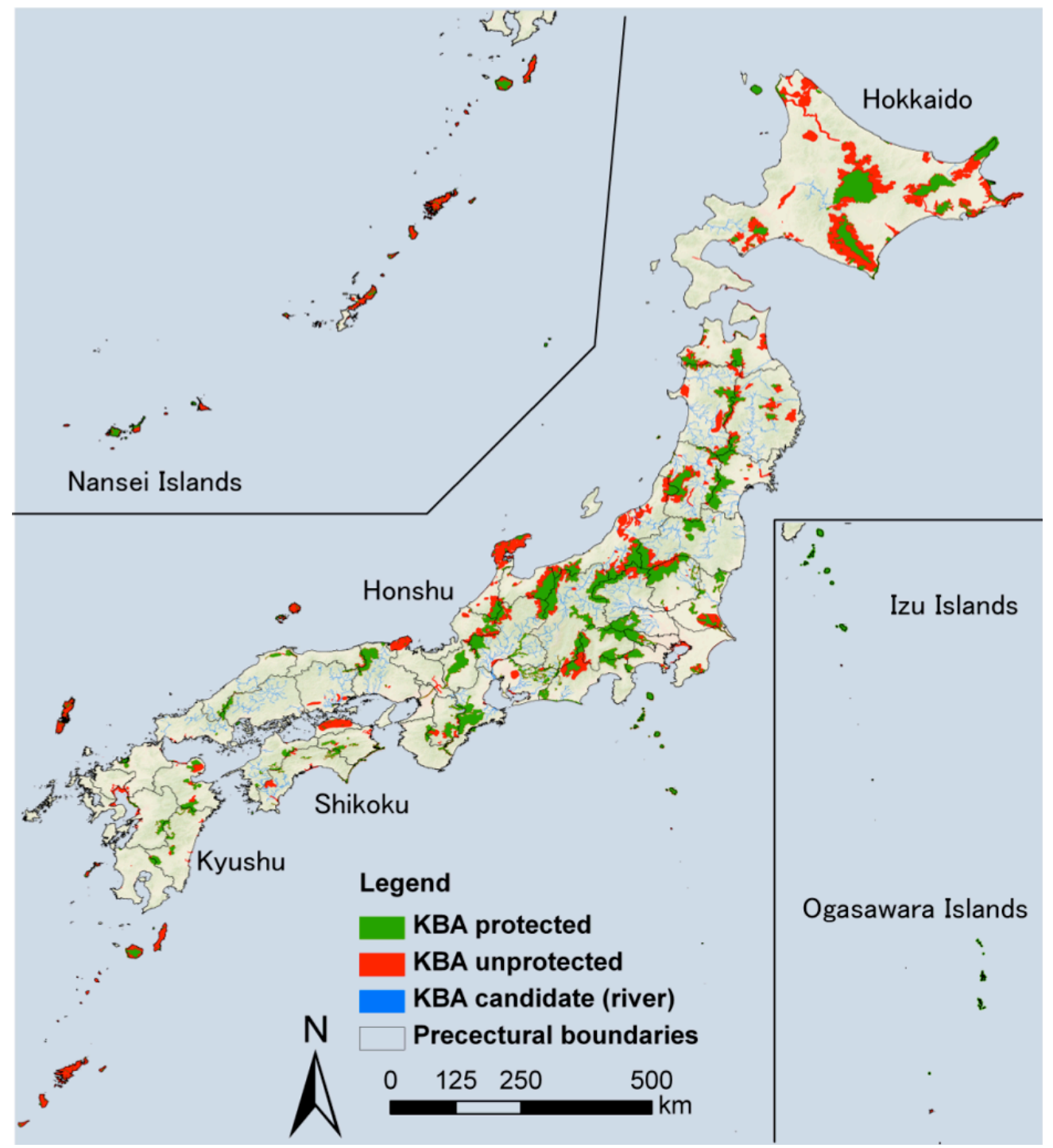

Image 1. KBAs and KBA candidates in Japan 
Table 3. Area, number, coverage and protected-area status of KBAs in the Japan Hotspot and its components

\begin{tabular}{|l|c|c|c|c|c|c|c|}
\hline \multirow{2}{*}{ Components } & \multirow{2}{*}{$\begin{array}{c}\text { Area } \\
\left.\mathbf{( k m}^{2}\right)\end{array}$} & \multirow{2}{*}{ \# KBAs } & \multicolumn{2}{|c|}{ Area $\left.\mathbf{( k m}^{2}\right)$ of } & \multirow{2}{*}{$\begin{array}{c}\text { \% land in } \\
\mathbf{K B A s}^{3}\end{array}$} & \multirow{2}{*}{ \# KBAs protected $^{4}$} & \multirow{2}{*}{ \% KBAs protected $^{3}$} \\
\cline { 4 - 5 } & 374,773 & 228 & 68,248 & 65,812 & 17.6 & 156 & 54.7 \\
\hline Japan & 77,967 & 26 & 17,660 & 17,092 & 21.9 & 17 & 36.3 \\
\hline Hokkaido & 228,489 & 118 & 39,684 & 39,345 & 17.2 & 85 & 65.7 \\
\hline Honshu & 18,483 & 12 & 2,021 & 1,748 & 9.5 & 9 & 45.6 \\
\hline Kyikoku & 37,543 & 21 & 2,403 & 1,931 & 5.1 & 11 & 76.7 \\
\hline Smaller Islands & 12,291 & 51 & 6,480 & 5,696 & 46.3 & 34 & 29.5 \\
\hline
\end{tabular}

1 - Area as calculated in GIS, which may differ from official record; ${ }^{2}$ - The area of KBAs including marine habitat; ${ }^{3}$ - The percentage of land in KBAs and the percentage of KBAs protected limited to terrestrial parts only; ${ }^{4}-\mathrm{A} \mathrm{KBA}$ is counted as protected if any part of the area within its boundaries is protected.

Table 4. Numbers of KBAs triggered by each of the criteria/subcriteria for each higher taxonomic group

\begin{tabular}{|c|c|c|c|c|c|c|c|}
\hline \multirow[b]{2}{*}{ Higher taxon } & \multicolumn{3}{|c|}{ Vulnerability } & \multicolumn{3}{|c|}{ Irreplaceability } & \multirow{2}{*}{$\begin{array}{l}\text { Total number of } \\
\text { KBAs triggered }\end{array}$} \\
\hline & CR & EN & vu & $\begin{array}{l}\text { Restricted- } \\
\text { range }\end{array}$ & $\begin{array}{c}\text { Congregations/ } \\
\text { Aggregations }\end{array}$ & $\begin{array}{l}\text { Biome- } \\
\text { restricted }\end{array}$ & \\
\hline Birds & 2 & 20 & 44 & 17 & 98 & 42 & 151 \\
\hline Mammals & 5 & 31 & 3 & 21 & - & - & 40 \\
\hline Reptiles & 1 & 2 & 7 & 0 & - & - & 7 \\
\hline Amphibians & 5 & 14 & 18 & 18 & - & - & 46 \\
\hline Fish & 29 & 35 & 12 & 0 & - & - & 60 \\
\hline Odonates & \multicolumn{2}{|c|}{391} & 22 & 0 & - & - & 49 \\
\hline Total number of KBAs triggered ${ }^{2}$ & 38 & 108 & 88 & 43 & 98 & 42 & 228 \\
\hline
\end{tabular}

1 Japanese Red List for Odonates uses a merged category of CR+EN. Species in CR+EN category were counted towards the EN category;

${ }^{2}$ Row totals and column totals do not equal the sums of row entries and column entries because most KBAs are triggered by more than one species and more than one criteria.

prefectural natural parks, wilderness areas, nature conservation areas, wildlife protection areas (both national and prefectural), and forestecosystem reserves.

If the presence data of the trigger species were located outside IBA or existing protectedarea boundaries, vegetation maps (Ministry of the Environment; available online: http://www. biodic.go.jp/english/kiso/fnd_f.html) and municipal boundaries were used to help define KBA boundaries.

\section{RESULTS}

We identified $228 \mathrm{KBAs}$, covering over $68,000 \mathrm{~km}^{2}$ (Image 1). Some KBAs extended into marine environment to account for trigger species that are dependent on brackish environment and shorelines. The terrestrial part covers a total of $66,000 \mathrm{~km}^{2}$, equaling $17.6 \%$ of the land area (Table 3 ). The islands stand out as particularly important conservation priorities. Western Honshu, Kyushu and Shikoku were low in percent of land in KBAs. Overall, about $30,000 \mathrm{~km}^{2}$ of the KBA extent is not protected. In addition, 50 rivers were identified as candidate KBAs for the presence of trigger species of fish and odonates. The specification of their boundaries is left to future work with more information from the sites.

All previously identified IBAs were included. Some IBAs were grouped; e.g. the Izu Islands KBA represents a group of eight IBAs. Many KBAs were delineated by expanding IBAs to include the presence localities of non-bird taxa and to incorporate existing protected-area boundaries. Seventy-seven sites were added in KBA triggered by other taxa (Table 4).

Alliance for Zero Extinction sites (AZEs) are a subset of KBAs that are identified by the presence of highly threatened species (CR or EN in the IUCN Red List) known to occur only in single sites globally. There are six AZEs identified in Japan (AZE, 2010). All of them were also identified as KBAs triggered by 
Table 5. Species occurring at only one KBA globally

\begin{tabular}{|c|c|c|}
\hline KBA (* if global AZE site) & Species (* if AZE trigger species) & IUCN Red List category ${ }^{1}$ \\
\hline \multirow{6}{*}{$\begin{array}{l}\text { Amami Islands* (include AZE site, } \\
\text { Tokunoshima) }\end{array}$} & Pentalagus furnessi & EN \\
\hline & Odorrana amamiensis & EN \\
\hline & Babina subaspera & EN \\
\hline & Crocidura orii & EN \\
\hline & Garrulus lidthi & VU \\
\hline & Tokudaia tokunoshimensis* & EN \\
\hline Biwako & Sarcocheilichthys biwaensis & -- (CR) \\
\hline Echigo Plain* & Mogera etigo* & EN \\
\hline Kumejima & Opisthotropis kikuzatoi & $\mathrm{CR}$ \\
\hline \multirow{3}{*}{ Miyako Islands } & Amphiesma concelarum & $--(E N)$ \\
\hline & Calamaria pfefferi & $\mathrm{DD}(\mathrm{EN})$ \\
\hline & Takydromus toyamai & $--(E N)$ \\
\hline \multirow{6}{*}{ Ogasawara Islands } & Indolestes boninensis & $\mathrm{CR}(\mathrm{CR}+\mathrm{EN})$ \\
\hline & Boninagrion ezoin & CR (VU) \\
\hline & Hemicordulia ogasawarensis & $\mathrm{EN}(\mathrm{CR}+\mathrm{EN})$ \\
\hline & Rhinogobius sp. BI & $\mathrm{LC}(\mathrm{CR})$ \\
\hline & Rhinocypha ogasawarensis & $\mathrm{CR}(\mathrm{CR}+\mathrm{EN})$ \\
\hline & Apalopteron familiare & VU \\
\hline Oki Island* & Hynobius okiensis* & $\mathrm{CR}$ \\
\hline Senkaku Islands & Mogera uchidai & $\mathrm{DD}(\mathrm{RR})$ \\
\hline Southern Alps & Hynobius katoi & $\mathrm{DD}(\mathrm{RR})$ \\
\hline \multirow{3}{*}{ Tsushima Islands* } & Rana tsushimensis & $\mathrm{LC}(\mathrm{RR})$ \\
\hline & Hynobius tsuensis & LC (RR) \\
\hline & Murina tenebrosa* & CR \\
\hline \multirow{5}{*}{ Yaeyama Islands } & Prionailurus bengalensis iriomotensis & $\mathrm{CR}$ \\
\hline & Odorrana supranarina & EN \\
\hline & Odorrana utsunomiyaorum & EN \\
\hline & Takydromus dorsalis & -- (VU) \\
\hline & Rhacophorus owstoni & LC (RR) \\
\hline \multirow{6}{*}{ Yambaru* } & Rhinogobius sp. BB & $--(E N)$ \\
\hline & Tokudaia muenninki* & $\mathrm{CR}$ \\
\hline & Limnonectes namiyei* & EN \\
\hline & Sapheopipo noguchii ${ }^{\star 2}$ & CR \\
\hline & Odorrana narina* & EN \\
\hline & Gallirallus okinawae* & EN \\
\hline
\end{tabular}

1 - Japanese Red List Categories (or KBA subcriteria) used for KBA identification are provided in parentheses if they are different from those in IUCN Red List; ${ }^{2}$ - Synonymous with Dendrocopos noguchii.

species other than those used to identify AZEs. Table 5 lists only five AZEs. The sixth AZE, Yatsugatake, has been identified for a species of conifer (Picea koyamae), which was a taxon not considered here for KBA identification, but the site was identified as KBA based on the presence of other trigger species. Only small fractions of five AZEs, Echigo Plain, Oki Island,
Tsushima Islands, Tokunoshima Island, Yambaru, are currently protected. In addition to the existing six AZEs, three KBAs may be considered candidates for new AZEs: Kumejima Island (one AZE trigger species), Ogasawara Islands (four AZE trigger species) and Yaeyama Islands (three AZE trigger species). The highest numbers of trigger species found at 
Table 6. Frequency distributions of the number of trigger species per KBA, and the number of KBAs per trigger species

\begin{tabular}{|c|c|c|}
\hline $\mathrm{n}$ & $\begin{array}{c}\text { The number of KBAs } \\
\text { holding } \mathrm{n} \text { trigger } \\
\text { species }\end{array}$ & $\begin{array}{l}\text { The number of trigger } \\
\text { species occurring in } n \\
\text { KBAs }\end{array}$ \\
\hline 1 & 73 & 75 \\
\hline 2 & 43 & 36 \\
\hline 3 & 33 & 22 \\
\hline 4 & 23 & 8 \\
\hline 5 & 12 & 12 \\
\hline 6 & 9 & 11 \\
\hline 7 & 11 & 8 \\
\hline 8 & 7 & 4 \\
\hline 9 & 2 & 5 \\
\hline 10 & 6 & 4 \\
\hline 11 & 3 & 3 \\
\hline 12 & 1 & 4 \\
\hline 13 & 1 & 0 \\
\hline 14 & 0 & 1 \\
\hline 15 & 0 & 6 \\
\hline 16 & 0 & 1 \\
\hline 17 & 0 & 3 \\
\hline 18 & 0 & 0 \\
\hline 19 & 2 & 0 \\
\hline 20 & 0 & 0 \\
\hline 21 & 0 & 0 \\
\hline 22 & 0 & 1 \\
\hline 23 & 1 & \\
\hline 24 & 1 & \\
\hline Total & 228 sites & 204 species \\
\hline
\end{tabular}

single KBAs were 24 on Yambaru, followed by 23 on the Yaeyama Islands and 19 on the Amami Islands (Table 6); all of which are in the Nansei Islands. Furenko-Nemuro in Hokkaido was the next richest with 14 trigger species. The majority (194 KBAs, $84 \%$ ), however, were triggered by five species or fewer.

Seven trigger species triggered 15 or more KBAs: Dymecodon pilirostris, Heteroscelus brevipes, Pipistrellus endoi, Myotis pruinosus, Anas platyrhynchos, Columbajanthina and Lestesjaponicas. Not surprisingly, however, the majority of trigger species triggered only a few KBAs (Table 6), because many trigger species are endemic to specific islands.

\section{DISCUSSION}

\section{Gaps}

The most important gaps in the protected area network were found to be the Nansei Islands, a string of islands extending southwest from southern tip of Kyushu, such as Amami Islands and Yambaru. A more detailed identification of priority sites within this island chain has been performed (WWF Japan, 2009), which should facilitate more focused local conservation actions. Freshwater (and brackish water) systems were also found to be generally under-represented in protected areas; e.g. northern Hokkaido and western Japan. Unprotected KBAs were identified not only in mountainous and other more natural habitats, but also in semi-natural and agricultural areas; e.g. Echigo Plain, Noto Peninsula and Sanuki Plain. Taking into consideration the varying threats to and natural and social conditions of the areas identified as KBAs, the most appropriate form of protection, including the type of protected-area designation, should be determined on site-specific bases.

\section{Caveat and Limitations}

This analysis used existing protected-area boundaries where they contained locality records of trigger species and did not refine boundaries further. KBAs boundaries, if geographically overlapped with existing protected areas, could be delineated larger than they would be in absence of such protected areas. This was done in consideration to management efficiency and with the idea that there is no need to reduce the area of protection if the protection is already committed in the area covering KBAs. The delineation of KBA boundaries outside protected areas were done in ways to minimize adding to KBAs. This means that the priority site for new protection covers $8 \%$ of Japan's land is a stronger message for conservation actions than total area covered by KBAs is $18 \%$ of Japan's land.

Weareawareofseverallimitationsofthisfirstanalysis of KBA in Japan, and we describe three of them here. First, we recognize that the list of taxa included in the analysis is incomplete. In particular, grassland systems are not well represented, since, for example, plants and butterflies were not included as the trigger species.

This is not to say, however, that important sites for these taxa have not been selected as KBAs. Indeed, KBAs identified here include the top ten 
sites for plant endemism in Japan (Kato \& Ebihara, 2011). This suggests that many key sites meeting the irreplaceability criterion for plants have likely been included in the KBAs identified by this analysis.

Second, the degree of actual protection provided by the existing protected areas to the KBAs identified here should be viewed with caution. We expect that those types of protected-area designation used to define protected areas in this analysis provide some level of deterrent against harmful developments. However, it should be kept in mind that many of them do not provide sufficient enforceable protection. There are zonings within given types of protected area providing different levels of protection. However, this analysis did not distinguish these differences in protection; i.e., in effect, we considered all areas inside the boundaries of existing protected areas to be protected equally. This differs from the treatment of protected-area designation as applied to IBAs by Wild Bird Society of Japan, which considers as protected only those parts of protected areas with the higher protected status. In consideration of actual implementation and enforcement, these differences should be more carefully considered. Such refined analysis is subject of future development, and will result in larger gaps than shown here.

Third, river systems are important and no less than 50 rivers had the presence of trigger species. Currently the entire river stretches are selected as candidate KBAs. Connectivity from upstream to downstream, as well as fragility of the riverine ecosystems to human alteration, poses a challenge in delineating KBAs in rivers. Although precise delineations are yet to be done, the intention is to draw attention to freshwater systems of potential importance to stimulate conservation actions.

The selection of KBA relied on presence-only data. The KBA map only shows the areas known to be important. It does not, by any means, indicate that areas outside these KBAs were excluded because they were assessed and were found to be of low conservation values. Rather, this indicates that they are not included in KBAs because there was insufficient information to justify their inclusion. Most areas simply have not been surveyed. As new information becomes available, additional areas equally important as the KBAs identified here may be found.

Information on important sites, such as KBAs, must be communicated to local authorities. To bridge effectively sites of global conservation importance to on-the-ground conservation actions at local scales, communicating the global importance in local context will become increasingly important.

\section{Future Priorities}

Developing capacity in GIS for conservation purposes is important in both selecting the sites at finer scales so that they can be proposed as part of formal protection programs and in providing updated information to enable periodic review of KBAs. For this purpose, the next related development will be to operationalize the Conservation GIS Consortium that will provide the platform for collecting and exchanging biogeographic information in ways that are safe and reliable for both information providers and users.

In 2010, the international community agreed to expand effectively managed protected area network (at least to $17 \%$ of the terrestrial area; Aichi Target 11) and to avoid extinction and improve the status of known threatened species (Aichi Target 12) under the Convention on Biological Diversity's Strategic Plan for Biodiversity 2011-2020 (see http://www.cbd.int/sp/ targets/). Currently, protected areas in Japan collectively cover $20 \%$ of land area, but this KBA identification revealed that additional $8 \%$ of the land should be protected or properly manged. As additional taxa (e.g., plants and butterflies) are included in the analysis, the number and the area of KBAs will certainly increase. To achieve these global Aichi Targets, this KBA analysis suggests that Japan's national target should seek securing appropriate management to $28 \%$ of the land.

\section{REFERENCES}

AZE (2010). Alliance for Zero Extinction: 2010 Update. http:// www.zeroextinction.org (accessed on 31 October 2011).

Biodiversity Center of Japan (2008). Catalog of Surveys on Natural Environment. Biodiversity Center of Japan, Nature Conservation Bureau, Ministry of the Environment, Yamanashi, Japan, 146pp (In Japanese). Available at: http://www.biodic.go.jp/mokuroku/pdf/mokuroku all.pdf (accessed on 31 October 2011).

Eken, G., L. Bennun, T.M. Brooks, W. Darwall, L.D.C. Fishpool, M. Foster, D. Knox, P. Langhammer, P. Matiku, E. Radford, P. Salaman, W. Sechrest, M.L. Smith, S. Spector \& A. Turdoff (2004). Key Biodiversity Areas as Site Conservation Targets. BioScience 54: 1110-1118.

IUCN (2009). IUCN Red List of Threatened Species. Version 2009.1 Downloaded from http://www.iucnredlist.org. 
Spatial data, available at http://www.iucnredlist.org/technical-documents/spatialdata (accessed on April 18, 2010).

IUCN (2010). IUCN Red List of Threatened Species. <www.iucnredlist.org>. Downloaded on 14 March 2010.

Kato, M. \& A. Ebihara (2011). Endemic Plants of Japan. A Book Series from the National Museum of Nature and Science No. 11. Tokai University Press, Kanagawa, 503pp (In Japanese).

Langhammer, P.F., M.I. Bakarr, L.A. Bennun, T.M. Brooks, R.P. Clay, W. Darwall, N. De Silva, G.J. Edgar, G. Eken, L.D.C. Fishpool, G.A.B. de Fonseca, M.N. Foster, D.H. Knox, P. Matiku, E.A. Radford, A.S.L. Rodrigues, P. Salaman, W. Sechrest \& A.W. Tordoff (2007). Identification and Gap Analysis of Key Biodiversity Areas: Targets for Comprehensive Protected Area Systems. IUCN Best Practice Protected Area Guidelines Series No. 15. IUCN, Gland, Switzerland.

Ministry of the Environment (2001). Important Wetlands 500. Available at: http:// www.sizenken.biodic.go.jp/wetland (accessed on 1 June 2009).

Ministry of the Environment (2006, 2007). Red List of Threatened Species of Japan. Available at: http://www.biodic.go.jp/rdb/rdb_top.html (accessed on 1 June 2009).

Mittermeier, R.A., P. Robles-Gil, M. Hoffmann, J. Pilgrim, T. Brooks, C.G. Mittermeier, J. Lamoreaux \& G.A.B. da Fonseca (eds.) (2004). Hotspots Revisited: Earth's Biologically Richest and Most Endangered Terrestrial Ecoregions. CEMEX, Monterrey; Conservation International, Washington D.C.; and Agrupación Sierra Madre, Mexico.

Natori, Y., J. Silbernagel \& M. Adams (2011). Biodiversity conservation planning in rural Japan: integration of ecological and visual perspectives. In: Pavlinov, I.Y. (ed.). Research in Biodiversity - Models and Applications. InTech, pp. 285-306. Available from: http://www.intechopen.com/articles/show/title/biodiversityconservation-planning-in-rural-landscapes-in-japan-integration-of-ecologicaland-visual (accessed 15 October 2011).

Washitani, I. (2001). Traditional sustainable ecosystem 'SATOYAMA' and biodiversity crisis in Japan: conservation ecological perspective. Global Environment Research 5: $119-133$.

Wild Bird Society of Japan (2010). Important Bird Areas of Japan 2010. World Bird Society of Japan. Tokyo, 256pp.

Williams, K.J., A. Ford, D.F. Rosauer, N. De Silva, R. Mittermeier, C. Bruce, F.W. Larsen \& C. Margules (2011). Forests of East Australia: The 35th Biodiversity Hotspot, pp. 295-310. In: Zachos, F.E. \& J.C. Habel (eds.). Biodiversity Hotspots. Springer-Verlag, Berlin Heidelberg.

WWF Japan (2009). WWF Japan Nansei Islands Biological Diversity Evaluation Report. WWF Japan, Tokyo, 178pp.
Acknowledgements: This project benefited from expert information provided by Dr. Masafumi Matsui, Dr. Kazumi Hosoya, Dr. Nobuo Ishii, Dr. Takuma Hashimoto, Mr Hiromune Mitsuhashi, Mr. Mitsuhiko Toda, Mr. Hitoshi Imai, Dr. Sachiko Yasui-Kamijo, Dr. Yuya Watari, Dr. Ken Sugimura, and Dr. Kazuto Kawakami, and Mr. Takehiko Sato. Ms Satoko Shirai provided valuable assistance. Conservation International would like to give special thanks to the Biodiversity Center of Japan, Ministry of the Environment for allowing use of the data from the National Survey on the Natural Environment. The project (non-bird taxa) was made possible by a financial support from Keidanren Nature Conservation Fund to Conservation International during 2009-2011.

Author Details and Contributions:

YoJI NATORI is the Ecosystem Policy Manager at Conservation International Japan. His current responsibilities include national and international biodiversity policy, management of a forest restoration project, and mainstreaming of biodiversity into society including the outreach of KBA. He led the study and preparation of the manuscript.

MARI KOHRI is currently a researcher at Tokyo Metropolitan University and the principal investigator of a Grant-in-Aid project, "Developing a mapping method for selecting biodiversity conservation priority area and for invasive species measures in the oceanic islands" from Japanese Ministry of Education, Culture, Sports, Science \& Technology. She supported the process as a consultant to $\mathrm{Cl}$, and collected distribution information of KBA trigger species to produce draft KBA mapping. SeIJI HaYama is the Head of Nature Conservation Office, Wild Bird Society of Japan. He is involved in conservation, monitoring and research in IBA sites. He also conducts lobbying activities. He provided information on IBAs to facilitate the KBA identification process.

NaAmal De Silva is the Director of Conservation Priorities and Outreach at Conservation International. With background in identifying globally significant sites for biodiversity conservation, her current role includes developing Cl's institutional framework for identifying geographic priorities and helping to link science staff in $\mathrm{Cl}$ headquarters with technical staff in the field. She advised the study by providing her experiences in the similar exercises in other countries.

All the authors participated in a workshop on conservation priority sites in Tokyo in September 2010 